\title{
PRATICANDO A DOCÊNCIA REFLEXIVA E A FORMAÇÃO CRÍTICA NA UNIVERSIDADE: A EXPERIÊNCIA DA DISCIPLINA DE ANTROPOLOGIA NA EDUCAÇÃO'
}

Leiry Kelly Oliveira ${ }^{2}$

\section{INTRODUÇÃO}

O presente trabalho busca refletir sobre o desafio que representa a formação de um educador crítico-reflexivo, perfil de egresso desejado pelos cursos de licenciatura do país. Tomando como base o perfil de profissional desejado pelo curso de Pedagogia da Universidade Federal do Ceará (UFC) e o conceito de docência reflexiva de Freire (1983) e Schön (2000), analisa-se neste a artigo experiência desenvolvida na disciplina Antropologia da Educação. Sob o argumento da necessidade de construção de um olhar etnográfico nos futuros professores e da aplicação de conceitos antropológicos básicos à educação, os alunos foram instigados à reflexão, desafiados a pesquisar e compreender a sua formação intelectual a partir de sua trajetória familiar e escolar.

Observou-se, ao longo da experiência, que os alunos, apesar de em sua maioria serem frutos de uma educação básica bancária e irreflexiva, e que se perpetua pelo curso superior (BESERRA; OLIVEIRA; SANTOS 2014), são capazes de um grande salto qualitativo quando desafiados e orientados no sentido de saírem da "zona de conforto acadêmico" à qual foram acostumados ao longo de suas trajetórias escolares. Ou seja, estão dispostos a abandonar o velho hábito de aprendizagem passiva e se tornarem ativos e autônomos em seu processo de formação. Tal empreendimento, porém, não é, em geral, motivado pelos próprios professores. Ao contrário, observou-se que grande parte deles se sente incomodada ao se ver objeto de reflexão dos seus alunos, situação que também os tira de sua "zona de conforto" e desafia a hierarquia

\footnotetext{
${ }^{1}$ Agradeço a professora Bernadete Beserra pelo incentivo à apresentação deste trabalho e pela orientação durante a monitoria.

${ }^{2}$ Graduanda em Pedagogia pela Universidade Federal do Ceará. E-mail: leiry.kelly@hotmail.com
} 
de poder da instituição do ponto de vista de quem pode pesquisar e representar quem (BESERRA 2004).

\section{A DOCÊNCIA REFLEXIVA: DESEJADA, MAS DIFICILMENTE INSTIGADA NA FORMAÇÃO DOCENTE}

Analisando o projeto político pedagógico (PPP) de quatro cursos de Pedagogia referência no $\mathrm{Brasil}^{3}$, notamos que em seu perfil de egresso existe um desejo em comum, algumas vezes expresso através de termos diferentes, o da formação de um docente crítico e reflexivo de sua própria prática. Tomando como base o PPP do curso de Pedagogia da Universidade Federal do Ceará (2014), encontramos como uma das habilidades desejadas para o egresso do curso a "capacidade crítico-reflexiva sobre sua prática, articulando a formação inicial à continuada."

Mas o que vem a ser a docência reflexiva? Diversos teóricos do campo educacional se referem ao termo docência reflexiva. Na região Nordeste é dada muita ênfase aos ensinamentos de Paulo Freire sobre a necessidade de reflexão sobre a prática no sentindo de possibilitar a autonomia do educando. Durante observação participante realizada por alunos da disciplina de Antropologia da Educação ao longo da duração da disciplina, foi evidenciado pelos próprios estudantes que não é raro que professores indiquem a leitura de livros de Freire, tal como o Pedagogia da Autonomia, que trazem em si saberes ditos essenciais à prática docente, tais como pesquisa, criticidade e reflexão sobre a prática. Porém, ao mesmo tempo em que essa criticidade e reflexão é estudada teoricamente em sala de aula, raramente é praticada. Ou seja, é algo que os professores em formação leem sobre, fazem provas e seminários sobre, mas raramente a veem praticada, inclusive pelos próprios professores que a defendem.

Outro autor que aborda o conceito de docência reflexiva é Donald Schön (2000). Através do estabelecimento de noções fundamentais como o conhecimento na ação, reflexão na ação, reflexão sobre a ação e reflexão

\footnotetext{
${ }^{3}$ Foram analisados os PPPs dos Cursos de Pedagogia da Universidade Federal do Ceará, Universidade Federal de Pernambuco, Universidade de São Paulo e Universidade Federal de Santa Catarina.
} 
sobre a reflexão na ação, ele discute a importância da prática reflexiva no processo formativo de profissionais, pois é através dela que é possível desenvolver habilidades essenciais para a prática profissional. Se se entende a importância da reflexão e da criticidade como sendo, segundo Castelli (2012), instrumentos importantes que irão determinar as percepções, interpretações e direcionamento da tomada de decisões que permitirão que esses futuros professores enfrentem os problemas encontrados no cotidiano do trabalho docente, por que continua-se apenas a discursar sobre isto e não se cria possibilidades efetivas para que os alunos pratiquem tais conceitos ou discursos? A prática reflexiva e a criticidade são habilidades que são aprendidas e necessitam do exercício prático. Como refletir sem a prática? Como vivenciar sem o exemplo? Partindo dessas indagações, realizei a observação da disciplina de Antropologia da Educação e sua experiência de desnaturalização do "dar e assistir aula" e desafiar os alunos a refletirem sobre sua formação.

\section{A EXPERIÊNCIA DA ANTROPOLOGIA DA EDUCAÇÃO: UMA MUDANÇA DIDÁTICA PARA A PRÁTICA DA REFLEXÃO}

A disciplina, tal como ministrada semestralmente no curso de Pedagogia da Faculdade de Educação da UFC pela Professora Bernadete Beserra, possui três formas de avaliação essenciais à formação do docente crítico-reflexivo: um trabalho inicial de reflexão sociológica sobre a opção pelo curso de Pedagogia, a escrita de um diário de campo e uma pesquisa etnográfica experimental. Desde o início do semestre, os alunos são desafiados a participar de uma aula diferente: uma aula dialogada. A leitura dos textos-base da disciplina é obrigatória e o ensino dos conceitos antropológicas se desenvolve a partir do debate em sala de aula. Desde o início da disciplina, os alunos são convidados a experimentar o aprendizado na prática, ou seja, o "olhar antropológico" é construído a partir da observação e do seu controle através da escrita de um diário de campo. Neste, o aluno registra seu dia a dia na universidade e reflete sobre as práticas docentes de seus professores e as suas reações a elas, sempre atrelando essas reflexões aos conceitos e teorias apresentados na disciplina, em especial a teoria bourdieusiana. A partir da 
constatação da distância (ou proximidade) existente entre as práticas educacionais na instituição e o seu Projeto Político Pedagógico, os alunos escolhem os temas da sua preferência guiados pelo desejo de compreensão e solução dos problemas vivenciados e vão, assim, construindo suas hipóteses e caminhos específicos de pesquisa - uma pesquisa etnográfica experimental.

Para a compreensão da dinâmica da disciplina, bem como dos espaços de formação propiciados, foi realizada observação participante durante os dois semestres de 2013. No primeiro semestre, enquanto aluna da disciplina, e no semestre seguinte como monitora. Além da observação das aulas, realizei acompanhamento da construção dos diários de campo e pesquisas experimentais realizadas pelos alunos. Os dados colhidos através das observações foram sistematizados e interpretados buscando atrelar a concepção de formação docente utilizada na disciplina e o intuito de formação crítica e reflexiva do docente, presente no PPP.

Num primeiro momento, ao serem apresentados a uma aula dialogada, os alunos se sentem desconfortáveis. Tal desconforto é reflexo da formação bancária que recebem na educação básica e que persiste na educação superior. Educação essa que, segundo Freire (1983), mantém a contradição entre educador e educando e onde o professor é visto como transmissor do conhecimento e o aluno, passivo, atua apenas como receptor. Ao serem confrontados a sair de sua zona de conforto, os alunos iniciam o processo de relacionar as teorias estudadas na disciplina com o que é observado em seus diários de campo. Essa oportunidade de reflexão sobre a própria formação nos remete ao que Castelli (2012) expõe ao relatar a importância da preparação e formação de um profissional docente dialogante com a realidade, com o conhecimento, com as suas competências, com a pesquisa, com sua ação docente e suas relações no processo de ensinar e aprender na universidade.

Durante a construção de seus diários de campo, os alunos são desafiados a transformar o familiar em exótico, a partir da concepção de DaMatta (1987), situando os eventos do mundo diário à distância para poder questioná-los. Os alunos são levados a problematizar e refletir sobre suas trajetórias diárias e os aspectos de sua formação docente. Para continuar o processo de formação desse olhar etnográfico, os futuros docentes 
desenvolvem uma pesquisa de cunho etnográfico abordando aspectos que mais lhe chamam atenção no seu processo formativo. Dos diários de campo e das pesquisas experimentais surgem diversos debates, são vozes que se erguem para questionar a formação e como essa poderia ser mais efetiva. $O$ discurso da reflexão e da criticidade finalmente ganha corpo na prática.

Porém, notamos algo preocupante. Os próprios professores universitários, que dão aula sobre o ser reflexivo e que constroem esse perfil de egresso desejado, não estão prontos para aceitar essa formação ativa e questionadora. Assim como os alunos nos primeiros dias de aula da disciplina, alguns professores, ao serem questionados por alguns alunos e ao se verem como objeto de uma pesquisa - o que vem ao encontro da relação de poder existente entre quem pode representar quem ${ }^{4}$, sentem seu poder inquestionável ameaçado. Incomodados, tomam como pessoal ou político aquilo que possui um grande potencial de debate e construção de conhecimento: os questionamentos estudantis que aparecem durante as pesquisas. De fato, alguns professores passaram a atacar a experiência da didática e da pesquisa realizada na disciplina utilizando o argumento de que tal reflexão sobre suas práticas em sala de aula é antiética. Perde-se assim, a oportunidade de reelaborar saberes e refletir a formação docente. Fato que nos remete novamente a Castelli (2012, p. 2) quando esta afirma da urgência de que as universidades invistam

[...] na formação efetiva do corpo docente para que estes, possam vir a transformar as instituições em lócus de produção de ensino e pesquisa, e assim, um despertar de consciência de uma nova identidade, com novas concepções de ensino e um novo olhar no processo do desenvolvimento pessoal e institucional.

A disciplina de Antropologia da Educação, espaço desta observação, oferece muito mais do que os fundamentos antropológicos e culturais da educação, ou seja, vai além de seu papel curricular. A disciplina instiga os alunos à reflexão, desafiando-os a pesquisar e compreender a sua formação intelectual a partir do seu universo familiar, trajetória escolar e experiência como estudante de Pedagogia. Instiga-os a tornarem-se reflexivos e críticos do

\footnotetext{
${ }^{4}$ Para mais informações sobre essa relação de poder e representação na pesquisa, ver BESERRA, Bernadete. Quem pode representar quem? Notas sobre sentimentos e relações de poder numa pesquisa de campo. Etnia (Olavarría ), Olavarria, Argentina, v. 46-47, p. 27-43, 2004.
} 
que está ao seu redor, mas também de sua própria prática enquanto discente e docente.

\section{CONSIDERAÇÕES FINAIS}

A docência reflexiva, como postulada por Freire e Schön, se configura como um instrumento indispensável para a profissão docente e portanto deve ser trabalhada durante sua formação no ensino superior. No entanto, mais do que apenas a preocupação com aspectos técnicos, formar docentes exige uma compreensão profunda das razões pessoais e sociais para a escolha do ofício e, sobretudo, o aprendizado dessa reflexão crítica sobre a prática docente e os diversos contextos em que tem lugar deve ser pautada também numa experiência prática que exige a capacidade de avaliação mas, principalmente, de autoavaliação. Ser capaz de avaliar e refletir sobre sua docência, mas também sua formação docente.

A experiência didática e de formação na disciplina de Antropologia da Educação no curso de Pedagogia da UFC tem produzido dados muitos ricos, além de reflexões desenvolvidas pelos monitores e alunos da disciplina e apresentadas em encontros universitários. ${ }^{5}$ Pesquisas e relatos que descrevem e analisam diferentes aspectos do universo cultural e das práticas docentes e discentes. E que, apesar de certa fragilidade de alguns trabalhos experimentais de alunos devido a seu estágio ainda inicial na pesquisa, demonstram que o esforço de construir um olhar antropológico e crítico das próprias práticas cotidianas possibilitou a articulação entre conceitos, teorias e práticas e o salto de qualidade evidente no seu aprendizado.

Transformando o familiar em exótico, eles se deram conta da importância da reflexão sobre a relação entre os discursos e as práticas cotidianas e conseguiram desenvolver uma visão crítica da docência e deles próprios. Tais habilidades são fundamentais para uma formação mais ampla e de qualidade e que, por conseguinte, possibilitará uma atuação docente capaz de alcançar o perfil de egresso desejado: um educador reflexivo e crítico.

\footnotetext{
5 . Algumas reflexões também têm sido desenvolvidas pela própria professora, Bernadete Beserra e apresentada em encontros científicos, a exemplo do artigo A desnaturalização do 'dar/assistir aula' como estratégia de aproximação entre antropologia e educação na formação de professores, apresentado na XI REUNIÃO DE ANTROPOLOGIA DO MERCOSUL
} 


\section{REFERÊNCIAS}

BESERRA, Bernadete. Da antropologia da educação a uma didática antropológica. In: V Reunião Equatorial de Antropologia- XIV Reunião de Antropólogos do Norte e Nordeste, 2015, Maceió. Direitos Diferenciados, Conflitos e Produção de Conhecimentos. Maceió: EDUFAL, 2015.

BESERRA, Bernadete. Quem pode representar quem? Notas sobre sentimentos e relações de poder numa pesquisa de campo. Etnia (Olavarría ), Olavarria, Argentina, v. 46-47, p. 27-43, 2004.

BESERRA, Bernadete; OLIVEIRA, L. K. ; SANTOS, C. . Entre o populismo docente e o dom da fala discente: problemas do ensino básico que sobrevivem à formação superior em Pedagogia. Revista Dialectus, v. 5, p. 151-166, 2014.

CASTELLI, Maria Dinorá Baccin. A Formação Docente no Contexto do Ensino Superior. In: Seminário de Pesquisa da Região Sul - IX AnpedSul. Caxias do Sul, RS: Anais Online, 2012. Disponível em: < http://www.portalanpedsul.com.br/admin/uploads/2012/Formacao_de_Professor es/Trabalho/12_13_00_2595-7178-1-PB.pdf > Acesso em: fevereiro, 2016.

CASTELLI, Maria Dinorá Baccin. Docência Reflexiva no Ensino Superior: Processo Dialógico de Reelaboração dos Saberes. In: Seminário de Pesquisa da Região Sul - IX AnpedSul. Caxias do Sul, RS: Anais Online, 2012. Disponível em: < http://www.portalanpedsul.com.br/admin/uploads/2012/Formacao_de_Professor es/Trabalho/05_29_30_1210-6919-1-PB.pdf> Acesso em: maio, 2016.

DAMATTA, Roberto. Relativizando: uma introdução à antropologia social. Rio de Janeiro: Editora Rocco, 1987.

FACULDADE DE EDUCAÇÃO, UFC. Projeto Político Pedagógico do Curso de Pedagogia. Fortaleza: 2014.

FREIRE, Paulo. Pedagogia do Oprimido. Rio de Janeiro: Paz e Terra, 1983.

SCHÖN, Donald A. Educando o Profissional Reflexivo: Um Novo Design para o Ensino e a Aprendizagem. Porto Alegre: Artmed Editora, 2000. 